\title{
Ophthalmic Sports Trauma in Central India
}

\author{
Bhartendu Shukla* \\ Ratan Jyoti Nethralaya Ophthalmic Institute, India
}

ISSN: 2577-1914

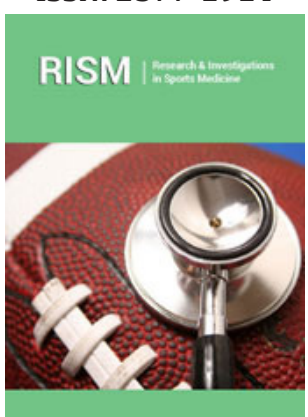

For HTML Version scan this QR code:

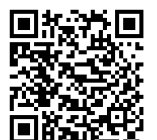

${ }^{* 1}$ Corresponding author: Bhartendu Shukla, Ratan Jyoti Netralaya Ophthalmic Institute, Madhya Pradesh, India

Submission: 啙January 31, 2019

Published: 留 March 07, 2019

Volume 4 - Issue 4

How to cite this article: Bhartendu $\mathrm{S}$. Ophthalmic Sports Trauma in Central India. Res Inves Sports Med. 4(4). RISM.000610.2019.

DOI: $10.31031 /$ RISM.2019.04.000595

Copyright@Bhartendu Shukla, This article is distributed under the terms of the Creative Commons Attribution 4.0 International License, which permits unrestricted use and redistribution provided that the original author and source are credited.

\begin{abstract}
As eye balls are in front of the body and are exposed for most of the time, they are quite likely to get injured. Sport includes all types of sporting events as well as games. Such injuries are more prone to occur in children and young persons who are most frequently involved in sports and games. In a study of 1744 eyes involved in ocular trauma, 214 were due to sports injury (12.27\%). As would be expected such injuries were more in males (82.5\%) than in females (17.5\%). The maximum incidence was found in children between 1-10 years (42.26\%) followed by children between $11-20$ years (35.51\%). There was a sharp decline after $20 \mathrm{yrs}$. (10.75\%). India is a peculiar country where there are two very different patterns of life styles-rural and urban. Although the rural population is more than double, the sports trauma is much higher in urban population (almost double). One reason for this anomaly may be the type of game. In rural areas usually children play with larger balls like, football or volley ball which are likely to cause less damage. Earlier two games, bow and arrow and gilli-danda were popular causing severe injury. However, they are not very common now and cricket has become popular. In urban areas games like hockey, cricket and golf are more common. These small harder balls cause more severe injuries. It is expected that the difference in sex ratio will decrease as women are participating in all types of sports.
\end{abstract}

\section{Introduction}

It may be mentioned at the outset that ocular trauma has not so far been given enough attention as it is due. Firstly, its incidence is rather difficult to assess. It occurs mainly in children who play and quarrel frequently resulting in eye injuries [1,2]. In many cases they hide it from parents or teachers for fear of punishment. Sometimes they are not able to give correct history. For the same reason the gravity of similar injury is much more in children than in adults. An adult of 70 years who is blinded or severely injured may have to suffer for 10 or 15 years more. However, a similar injury in a child of 5-10 years may cause serious handicap in life for 60-70 years. Lastly, ocular trauma is probably the only emergency left in ophthalmology which needs prompt relief or else serious visual loss may occur if not blindness.

One indication for this casual approach is obvious from the fact that the International Council of Ophthalmology during its conference has enumerates over 50 subjects for discussion in which ocular trauma is not yet identified as an independent subject. It may also be mentioned that the dividing line between sports and games is rather thin and for all practical purposes these two could be combined [3]. The incidence reported is quite variable and is ranging from $9.4 \%$ to $23 \%$ [4-9]. In India there is much difference in the life style of rural and urban population and needs different evaluation. The incidence also differs with age, sex, occupation and season.

\section{Material and Methods}

In a tertiary eye care hospital in central India a study was carried out for 8 years in which 1600 cases of ocular trauma were studied in detail. Beside the routing anterior and posterior segment examination necessary investigations in pathology and radiological investigations were carried out. Some cases had to be examined under general anesthesia.

\section{Observations and Analysis}

Out of 1600 cases studied 144 were bilateral. Hence the total number of eyes studied were 1744 . Out of these 214 eyes were involved in sports and games which were further analyzed and recorded in 10 tables. Table 1 shows that out of 1744 cases of ocular trauma 214 cases were due to sports injury (12.27\%). Table 2 shows sex incidence. Out of 214 cases $82.2 \%$ were males and 17.36 females. In age incidence, maximum was found in age group 
of 1 to 10 years (42. 26\%). In 11-20 years group also it was high (35.51\%). After that there was a steep fall (11 to $11.5 \%)$. Table 3 shows that only one third cases were from rural area and two third from urban area. Table 4 shows that many injuries occur in winter season $(41.5 \%)$ and few in summer season. The number of unilateral cases was double the number of bilateral cases Table 5-7 shows the games played in rural and urban areas respectively.

Table 1.

\begin{tabular}{|c|c|}
\hline Total Number of Traumatized Eyes & 1744 \\
\hline Eyes Involved in Sports Injury & 214 \\
\hline Percentage of Sports & $12.27 \%$ \\
\hline
\end{tabular}

Table 2: Sex incidence.

\begin{tabular}{|c|c|c|}
\hline Sex & Number & Percent \\
\hline Male & 176 & 82.24 \\
\hline Female & 38 & 17.26 \\
\hline Total & 214 & \\
\hline
\end{tabular}

Table 3: Residence.

\begin{tabular}{|c|c|c|}
\hline & Number & \% \\
\hline Rural & 71 & 33.18 \\
\hline Urban & 143 & 66.82 \\
\hline
\end{tabular}

Table 4: Season.

\begin{tabular}{|c|c|c|}
\hline Season & Number & Percent \\
\hline Summer & 74 & 34.48 \\
\hline Rainy & 51 & 23.83 \\
\hline Winter & 89 & 41.60 \\
\hline
\end{tabular}

Table 5: Laterality.

\begin{tabular}{|c|c|c|}
\hline & Number & Percent \\
\hline Unilateral & 145 & 67.78 \\
\hline Bilateral & 69 & 32.24 \\
\hline
\end{tabular}

Table 6: Rural games.

\begin{tabular}{|c|}
\hline Gilli Danda \\
\hline Football \\
\hline Kho kho \\
\hline Bow \& Arrow \\
\hline Hockey \\
\hline Wrestling \\
\hline Kabaddi \\
\hline Wrestling \\
\hline
\end{tabular}

Table 7: Urban games.

\begin{tabular}{|l|c|}
\hline 1 & Tennis \\
\hline 2 & Cricket \\
\hline
\end{tabular}

\begin{tabular}{|c|c|}
\hline 3 & Badminton \\
\hline 4 & Golf \\
\hline 5 & Table Tennis \\
\hline 6 & Hockey \\
\hline 7 & Squash \\
\hline 8 & Billiard \\
\hline
\end{tabular}

\section{Discussion}

Higher incidence in males (4 times) is understandable as they are more involved in sports and games. However, with rising incidence education and awareness in female's male dominance is likely to reduce. Females are playing almost all games including cricket, hockey and wrestling. More injuries in winters are expected as games are mostly played in this season. Low incidence in rainy season is also expected as almost all outdoor activities are restricted due to rains. Higher incidence urban area is rather unexpected as in India about $70 \%$ population is in the villages. Girls in villages usually do not play outdoor games and poor reporting may be another reason. In villages games are played by bigger balls like football, volley ball and basketball which do not inflict severe injury. However, some games like Gilli-Danda and bow \& are very risky but incidence of these games are educing. Cricket is becoming popular in rural areas also.

\section{Conclusion}

Sports and Games injuries are quite common all over the world. In North India $24 \%$ of sports injuries result in blindness [10]. Most of them can easily be prevented by supervision, education, awareness and early effective treatment. There is need for giving specific type of toys for different age groups. Young children should be supervised.

\section{References}

1. Shukla B, Nayar B (2009) In Clinical diagnosis and management of ocular trauma. In: Garg A, Jose MR, Shukla B (Eds.), JP Brothers Medical Publishers, New Delhi, pp. 283-285.

2. Danis RP, Neely D, Plager DA (2003) In Ocular Trauma: Principles and Practice. In: Kuhn FC, Dante JP (Eds.), Thieme Publications, New York, USA, pp. 307-309.

3. Shukla B (2004) In management of ocular trauma. In: Shukla B, Natarajan S (Eds.), CBS Publishers, New Delhi, India, pp. 323-324.

4. Malik SRK, Gupta AK (1968) J Al Ind Ophthal 16: 178.

5. Weerkon I Brit (1964) J Ophthal 48: 4421.

6. Ference K, Mester V, Mann L (2002) In ocular trauma. Thieme Publications, New York, USA.

7. Mathew (1988) Ind J Ophthal 16: 178.

8. Jain BC, Soni SR (1988) Ind J Ophthal 16: 178.

9. Blondale S, Norrel S (1984) Acta Ophthalmol 62: 378-390.

10. Mehta DK (2015) In ocular trauma-A comprehensive text. CBS Publishers \& Distributors, New Delhi, India, pp. 215-223. 